\title{
SUPPLY OF TROOPS WITH WEAPONS, EQUIPMENT AND MATERIAL AND TECHNICAL MEANS: PROBLEMS, TRENDS OF CHANGES, PROSPECTS
}

\section{AIDAR BERDIBEKOV \& AMANZHOL RAZBEKOV}

National University of Defense of the First President of the Republic of Kazakhstan, Elbasy, Nur-Sultan, Kazakhstan

ABSTRACT
The issues of equipping the Armed Forces with high-tech samples of weapons and military equipment and the necessary
means of logistics of their own production and determining the mechanism of their supply for the needs of the troops,
determining the prospects for the development of an integrated logistics system in accordance with the goals of the armed
forces and the available resources using a systematic approach are considered.
KEYWORDS: Equipment of the Armed Forces, The Logistics System, The Integrated System, Military-Technical Policy,
The Development of Weapons and Military Equipment, The Development of Military Technologies, Modernization \&
The Mechanism for Supplying the Armed Forces with Logistics

Received: May 20, 2020; Accepted: Jun 10, 2020; Published: Jul 11, 2020; Paper Id.: IJMPERDJUN2020285

\section{INTRODUCTION}

Equipping the Armed Forces with weapons, equipment, and the necessary means of material and technical support (hereinafter - MTO) of its own production is considered as a strategic task of any state that has always sought to keep this important sphere of economic defense under control (Gordienko,2010).

The main goal of any military-technical policy is to create and maintain an integral system of weapons of the country and its integrated system of matreial-technical support, ensuring the solution of defense tasks and ensuring the security of the state at the required level and the creation of a military-industrial complex in order to achieve this goal (Gordienko,2011).

\section{A SYSTEMATIC APPROACH TO THE SUPPLY OF TROOPS}

An analysis of the systems of state management of the military economy and military-economic activity shows that in most developed countries of the world there are always unique approaches and mechanisms for implementing relations between the state and the military sector, in which the key point is a combination of planned and market principles. Forms, methods and methods of managing the military economy, practiced and practiced today in industrially developed foreign countries, may be in demand today, when forming a mechanism for supplying material and technical means to the domestic Armed Forces.

Determining the prospects for the development of weapons and military equipment in accordance with the goals of the armed forces and the available resources requires the use of a systematic approach. One of these systematic approaches is the method called "planning-programming-budget development" (hereinafter - PPB). This method, which allows you to link the budget to targets, was first developed by analysts of an American research organization RAND Corporation. Subsequently, it was used in the planning and justification of military and militarytechnical tasks in many countries. 
The main point of the PPB system is to link goals, resources and available funds (financial capabilities) into a single program. Its development usually involves three stages:

- Justification of the tasks facing the armed forces and their "bricks", establishment of appropriate needs (planning);

- $\quad$ Determining the necessary composition of forces and means (programming);

- Conducting military-economic analysis, allocating the required funds (developing the budget, its main elements).

It is important to note that planning is carried out not by type, not by organizational structures, but by target programs. Programs consist of separate program elements. Programming is based on medium-term plans for the development of military-technical systems and the armed forces.

Since the process of development of military technologies is continuous, the methodology of program-target planning and management of this process should also be continuously developed. Its main aspects are:

- An evolutionary and technological approach to the creation of VVT and MTO tools, samples of VVT and its use in justifying the future appearance of the weapon system;

- Regulation of terminology in the scientific and technological field;

- Substantiation of scientific and technological priorities in the process of formation and implementation of the state armament program in the form of lists of critical technologies, as well as lists of scarce, strategic import-substituting materials that ensure the production of the most important samples of military hardware and MTO tools within the state armament program;

- Methodological aspects of the formation and financing of program activities related to the creation of scientific and technical reserves for advanced and non-traditional weapons;

- Features of fundamental, forecast and search research in the field of defense and security as an object of programtarget planning (Faramyazan,2006).

In the usual sense, military products (hereinafter referred to as VP) are primarily military equipment and MTO means, that is, means of performing combat tasks, military-technical equipment and material means for various types of support for military formations.this category makes up the bulk of military products. It also includes scientific and technical potential (hereinafter referred to as NTP), that is, the completed results of research, development and testing, embodied in design documentation, prototypes, layouts, software and scientific and technical reports, as a result of research and development (Anne Lise Bjørnstad, 2011).

Of course, for the development and production of EAP that meets modern threats, the state must have certain resources and competencies in this area, and most importantly, an integrated logistics system. The potential for creating an EAP depends on capacity and various factors. After all, only countries with a developed economy and science that have the potential to produce EAP and a high level of STP can create a truly popular, high-quality product. This is confirmed by the situation on the world arms market, where almost all the G20 countries are represented (Gunkin,2018). The potentials and factors affecting the ability to create military products are shown in figure 1. 


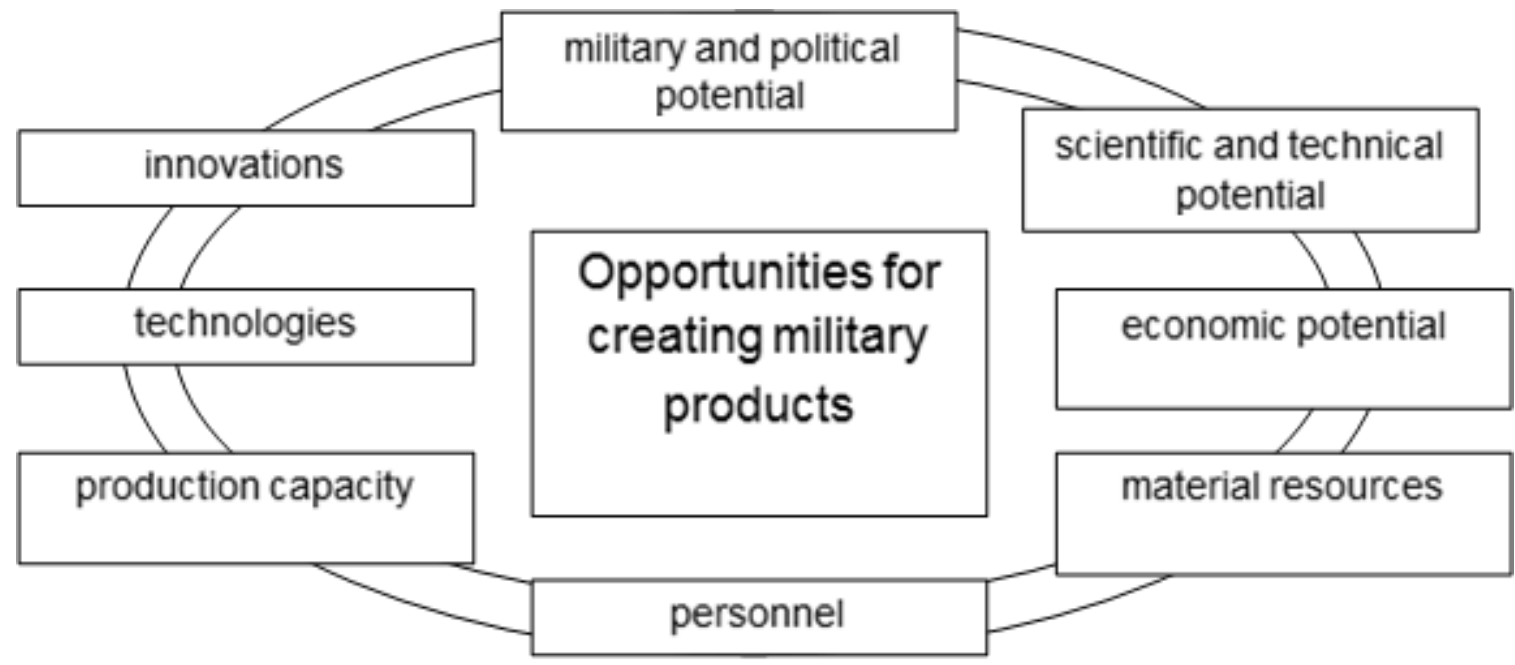

Figure 1: Potentials and Factors Affecting the Ability to Create Military Products.

Analysis of the evolutionary development of the concept of warfare shows that "set-centric war", "informationcentric war" and "knowledge-centric war" is a derivative of IT technology and therefore they can be combined into one category.

In addition, the analysis shows that: the potential for improving the effectiveness of traditional weapons and military equipment has already reached its physical limits. This is due to the fact that the effective solution of promising tasks is no longer possible only on the basis of improving traditional military technologies due to significant financial and economic restrictions and a significant lag in most scientific and technological areas from the level of the leading countries of the world (Burenok,2019).

\section{MECHANISM FOR SUPPL YING TROOPS}

Currently, the potential of the national Armed forces of a state have traditionally increased by upgrading and acquisition of modern weapons and equipment and means of MTO and go to system to develop high-tech weapons not allow the scientific and technological lagging behind the leading countries lack scientific and technological base and creating weapons research and testing complex. However, the country has the opportunity to make a scientific and technical breakthrough on the basis of new technologies, to create not new weapons, but to develop the latest military technologies and dual - use technologies (5 - and 6-technological modes), based on the use of existing industrial potential (4-technological mode). At the same time, the acquisition of modern samples of military equipment should be carried out on the basis of a program-oriented approach.

Modernization of the military-technical policy of the state requires solving the issues of creating weapons systems that ensure the transition from the acquisition system to the system of developing high-tech elements to existing weapons and creating the ability of the country to create them independently (Mukanov,2019).

The draft of a unified mechanism for supplying armies with high-tech weapons and military equipment and MTO means is presented in the table.

Table 1: Project of a Unified Mechanism for Supplying Armies 


\begin{tabular}{|c|l|l|l|}
\hline № & Functions & \multicolumn{1}{|c|}{ Ongoing Work } & \multicolumn{1}{c|}{ Executors } \\
1. & Planning & $\begin{array}{l}\text { Formation of principles and procedural rules that ensure the } \\
\text { development of the latest military and dual-use technologies, } \\
\text { determination of priorities for their allocation, implementation of } \\
\text { management and control, conclusion of contracts }\end{array}$ & Ministry of defence \\
\hline 2. & Development & $\begin{array}{l}\text { A complex of research projects to create the latest military } \\
\text { technologies, mock-UPS and prototypes. OCD complex. }\end{array}$ & $\begin{array}{l}\text { Research Institute, } \\
\text { Higher educational } \\
\text { institution, Design } \\
\text { Bureau }\end{array}$ \\
\hline 3. & Production & Production of high-tech samples of components for VVT & $\begin{array}{l}\text { Factories, Startups, } \\
\text { MIP }\end{array}$ \\
\hline 4. & Provision & $\begin{array}{l}\text { Equipping the armed forces, other troops and military formations. } \\
\text { Maintenance, MAINTENANCE, repair }\end{array}$ & $\begin{array}{l}\text { Types and types of } \\
\text { troops }\end{array}$ \\
\hline 5. & Distribution & Types and types of troops & Ministry of defence \\
\hline
\end{tabular}

The implementation of a program-oriented approach to the creation of elements for military systems is carried out by the Ministry of Defense within the framework of a system that can be defined as follows: "The acquisition system of the Ministry of defense is a single unified system within which planning, development, production, deployment, provision (maintenance, repair, etc.) and distribution of all types of material and services between organizational components are carried out." The function of this system is to formulate General principles and procedural rules that ensure the development of the latest systems for IWT, in accordance with which the required resources are determined and priorities for their allocation are set, control over the acquisition process is managed, and contracts for all necessary types of reporting are concluded.

The system for purchasing weapons and military equipment of the Ministry of defense is the main part of the entire state acquisition system and essentially forms its basis. In General, it makes it possible to effectively plan the development of the latest military technology for air defense samples, organize their development and production, and control the process at all stages - from concept research to disposal.

The work performed on the program-targeted financing of research works is related to the creation of specific systems for IWT. Individual programs and projects carried out by scientists, continues on an average for 1-3 years and brought, if successful, to the stage of demonstration tests of experimental samples, and then transmitted to the relevant bodies of the Ministry of defence or the armed forces, in some cases, other government offices to implement the obtained results in the systems and means of armed struggle.

The main goal of any military-technical policy is to create and maintain an integrated system of weapons of the country, ensuring the solution of defense tasks and ensuring the security of the state at the required level and the creation of a military-industrial complex in order to achieve this goal.

The strategic goal of technical equipment is to ensure that the weapons system meets the level of security threats and its allies; the tasks, structure of the armed forces, forms and methods of their combat use; and the possibilities of budget financing of national defense expenditures.

The evolution of the concept of warfare from "platform-centric war" is due to scientific and technological development. At its core, this is the evolution of military technologies, which have always been the most advanced and most popular. Theirrole in military construction increases exponentially, eventually leading to qualitative changes in the forms and methods of military confrontation (Kosal, 2010). 


\section{CONCLUSIONS}

Thus, the tasks of state defense require to start developing fundamentally new systems for weapons and military equipment that meet the requirements of scientific and technological progress. This requires a certain methodology, which is based on the theory of knowledge and formal logical method, the content of which is formal logic as a philosophical science of correct thinking.

The program-target approach to creating high-tech elements for existing models of weapons and military equipment is one of the main tasks of the methodology for the development of high-tech weapons and military equipment.

The transition to program-target planning includes the development of comprehensive plans for providing solutions to the main tasks of the armed forces, including the development, production, operation in the army at the optimal matching needs of the armed forces budget allocations. A set of new research works is being developed to create a methodology for scientific justification of the development of weapons and military equipment and to develop on this basis organizational principles and recommendations for improving the management system of military technical support of the armed forces.

\section{ACKNOWLEDGEMENTS}

This article is published as part of the research work of program-targeted funding № BR 05236855 "Military-technical and military-technological support of the defense and security of the Republic of Kazakhstan on the basis of economic pragmatism".

\section{REFERENCES}

1. Gordienko D. V. Military economy in market conditions Center for strategic assessments and forecasts, www.csef.ru. №20.Moscow -12.2010

2. Gordienko D. V. Military-economic confrontation in the modern world.Analytical report. Center for strategic assessments and forecasts, www.csef.ru. Moscow -2011.

3. Fundamentals of the military economy. Experience and prospects of development of the military-industrial complex of the Republic of Kazakhstan. Textbook. JSC "CVSI" 2013.

4. Faramyazan R. A. Borisov V. V. Transformation of the military economy of the XX-beginning of the XXI century. Textbook.Institute of world economy and international relations of the Russian Academy of Sciences. Moscow 2006.

5. Anne Lise Bjфrnstad.. Exploring Network Organization in Military Contexts: Effects of Flatter Structure and More Decentralized Processes/ Military Psychology, 23:315-331, 2011, Copyright @ Taylor \& Francis Group, LLC ISSN: 0899-5605/

6. Gunkin. Military products: concept, role and classification.VIII all-Russian scientific and practical conference. Tula: Tulsu Publishing house, 2018

7. Burenok V. M. Predicting the future appearance of the weapon system // Weapons and economy. - 1 (47) / 2019

8. Mukanov A. K., Khalikov D. K., Mukanov M. A. Military technologies of the XXI century. Information collection of the nuo, no. 3,2019

9. Methodological bases and regulations of management of research and development in high-tech industries / Ed. by B.S. Aleshin and A.V. Dutov. - Moscow: SIC "Institute named after N. E. Zhukovsky", 2017.

10. Burenok V. M., Ivlev A. A., Korchak V. Yu. Development of military technologies of the XXI century: problems, planning, implementation. - Tver: The Dome, 2009. 
11. M. E. Kosal (ed.). Disruptive and Game Changing Technologies in Modern Warfare, Advanced Sciences and Technologies for Security Applications, https://doi.org/10.1007/978-3-030-28342-1_11.

12. Richard L. Kugler. Case Studies in National Security Transformation/Number 14, p,32.

13. Guosheng, H. GuDaming, g., Li Xiangbo, L., and X. Lukuo (2013). Corrosion Behavior of Oxyacetylene Flame Sprayed Zn-Ni Composites Coating with Spray-dried Agglomerating Powders in Natural Seawater, Int. J. Electrochem. Sci., 82905 - 2917.

14. Ganesh, M. "Design of Airship for Aerial Surveillance and Communication Using Knowledge Based Engineering." International Journal of Mechanical and Production Engineering Research and Development (IJMPERD) 8.1 (2018): 17-26.

15. Hammer, P., F. C. dos Santos, B. M. Cerrutti, S. H. Pulcinelli and C. V. Santilli (2012). Corrosion Resistant Coatings Based on Organic-Inorganic Hybrids Reinforced 264 Developments in Corrosion Protection by Carbon Nanotubes, Recent Researches in Corrosion Evaluation and Protection, Prof. Reza ShojaRazavi (Ed.), ISBN: 978-953-307-920-2.

16. Hara, M., Ichino, R., Okido, M., and N. Wadab (2003). AlN formation and enhance- ment of high-temperature oxidation resistance by plasma-based ion implantation, Surf. Coat. Technol. 169-170, 359-362

17. Katz, Yaron. "Contrasts of Technology and Public Supervision in Israel's Media Policy."International Journal of Communication and Media Studies (IJCMS) 7. 4, Oct 2017, 13-20.

18. Hunag, Y. and J. Chen (2012). The Development of an Anti-corrosion Wrapping Tape and its Corrosion Protection Effect Evaluation on Mild Steel in Marine Splash Zone, Int. J. Electrochem. Sci., 7, 7121 - 7127.

19. Ige, O.O., Shittu, M.D., Oluwasegun, K.M., Olorunniwo, O.E. and Umoru, L.E. (2012). Eco-friendly Inhibitors for Erosioncorrosion Mitigation of API-X65 Steel in CO2 En- vironment, Ife Journal of Technology, 21 (2), 43 - 48.

20. Ganesh, M. "Design of Airship for Aerial Surveillance and Communication Using Knowledge Based Engineering." International Journal of Mechanical and Production Engineering Research and Development (IJMPERD) 8.1 (2018): 17-26.

21. Iroh, J. O., Zhu, Y., Shah, K., Levine, K., Rajagopalan, R., Uyar, T., Donley, M., Mantz, R., Johnson, J., Voevolin, N. N., Balbyshev, V. N., and A. N. Khramov (2003). Electro- chemical synthesis: A novel technique for processing multi-functional coatings, Prog. Org. Coat., 47: 365-375.

22. Khaled M. and E. Hashem (2011). Strengthening of Anticorrosion Passivity by Newly Developed Multi-silicon Coatings, Journal of Chemical Engineering and Materials Science, 2(1), 1-11.

23. Krishnamurthy, A., Gadhamshetty, V., Mukherjee, R., Chen, Z., Ren, W., Cheng, HM, and N. Koratkar (2013). Passivation of microbial corrosion using a graphene coating, Carbon, 56, 45-59.

24. sreekala, G. "Technology's Role in Commodification of Not-For-Profit Media. "International Journal of Communication and Media Studies (IJCMS) 4, Oct 2017, 53-60.

25. Lamaka, S.V., Zheludkevich, M.L., Yasakau, K.A., Serra, R., Poznyak, S.K., and M.G.S. Ferreira (2007). Nanoporoustitania interlayer as reservoir of corrosion inhibitors for coatings with self-healing ability, Prog. Org. Coat., 58, 127 - 135.

26. Lunder, O., Simensen, C., Yu, Y., and K. Nisancioglu (2004). Formation and charac-terisation of Ti-Zr based conversion layers on AA6060 aluminium, Surf. Coat. Tech- nol. 184, 2-3, 278- 290.

27. Nurakov S., Belotserkovsky M.A., Togusov A.K., Tulebekova A., Belikov K.L. (2018). Modern spraying technologies of wearresistant and protective coatings. Nur-Sultan: National Defense University named after the First President of the Republic of Kazakhstan - Leader of the Nation, 125.

28. Nurakov S., Belotserkovsky M., Merzadinova G., Aitlessov K. (2019). Modification of sprayed with supersonic coatings by 
microplasma oxidation. Procedia Computer Science, 149, 319-323.

29. Nurakov S., Atlasov K. (2017). the Relationship of roughness and functional properties of surfaces. Bulletin of the Gumilyov ENU, 4, 137-141.

30. Nurakov S., Belotserkovsky M., Suleimenov T., Aitlessov K. (2019). Application of chemical-thermal treatment for hardening of sprayed with supersonic coatings. Procedia Computer Science 149, 360-364.

31. Polyansky S. N., Butakov S. V., Alexandrov V. A., Lazareva L. Yu. Surface preparation for applying anticorrosive coatings on metal structures and details of mechanisms made of carbon steels. Modern problems of science and education, 2014, 4.

32. Suslov A. G., Bezylazny V. F., Panfilov Yu. V. (2008). Engineering of surfaces of details. - Moscow: Mashinostroenie, 316.

33. Zhaoxin Rena, Bing Wangb, GaomingXiangb, Dan Zhaoc, LongxiZhenga (2018). Supersonic spray combustion subject to scramjets: Progress and challenges. Progress inAerospace Sciences, 21, 20-23. www.elsevier.com/locate/paerosci

34. Stony Brook (2020). Progress in Supersonic Spray Combustion Modeling. AIAA Life Member and Associate Fellow.

35. Stony Brook (2019). Evaluating the Correlations for Supersonic Spray Combustion. AIAA SciTech Forum, 7-11 January, San Diego, California.

36. Stony Brook (2018). Dynamics of Supersonic Spray Combustion. AIAA Propulsion and Energy Forum, July 9-11, Cincinnati, Ohio.

37. Tokyo Scinutsu Co. Ltd (2006). Application guide manual for surfcom series surface roughness \& waviness parameters. Tokyo, 96. 
